\title{
Energy Consumption and Carbon Dioxide Emissions in Rail and Road Freight Transport in Spain: A Case Study of Car Carriers and Bulk Petrochemicals
}

\author{
A. GARCÍA-ÁLVAREZ, ${ }^{1}$ P. J. PÉREZ-MARTÍNEZ, ${ }^{2}$ \\ and I. GONZÁLEZ-FRANCO ${ }^{1}$ \\ ${ }^{1}$ Spanish Railway Foundation (FEF), Madrid, Spain \\ ${ }^{2}$ Sustainable Economy of Natural Environment Group (ECSEN), Universidad Politécnica de Madrid, Madrid, Spain
}

\begin{abstract}
This article provides a new methodology for estimating fuel consumption and emissions by enabling a correct comparison between freight transportation modes. The approach is developed and integrated as a part of an intelligent transportation system dealing with goods movement. A key issue is related to energy consumption ratios and consequent $\mathrm{CO}_{2}$ emissions. Energy consumption ratios are often used based on transport demand. However, including other ratios based on transport supply can be useful. Furthermore, it is important to indicate which factors are associated with variations in energy consumption and emissions; especially of interest are parameters that have a higher incidence and order of magnitude, in order to fairly compare and understand the difference between transport modes and sub-modes. The study finds that the use of an energy consumption equation can improve the quality of the estimates. The study proposes that coefficients that define the energy consumption equation should be tested to determine market niches and sources of improvement in energy consumption according to the category of vehicles, fuel types used, and classes of products transported.
\end{abstract}

Keywords Consumption Equation; Energy Efficiency; Equivalent Tons; Spain

\section{INTRODUCTION}

Energy consumption by different modes of surface freight transport, rail and road, is influenced by direct and indirect factors. Direct factors are related to the actual use of the vehicle (train and truck), and indirect factors are related to the construction and maintenance of infrastructure as well as production (fuels and vehicles) and vehicle maintenance (Van Wee et al., 2005). Direct factors can in turn be divided into logistical, technical, and operational factors.

Logistical factors mainly include the load factor-the measurement of the extent to which the capacity of the vehicle is used-and the network characteristics of surface transport infrastructure.

Address correspondence to P. J. Pérez-Martínez, Sustainable Economy of Natural Environment Group (ECSEN), Universidad Politécnica de Madrid, C/Ramiro de Maeztu s/n, 28040 Madrid, Spain. E-mail: pjperez@ caminos.upm.es
Technical factors are related to specific vehicle characteristics such as weight, capacity, engine, fuel type, and aerodynamics. Technical factors are partly influenced by the efforts carried out by vehicle manufacturers to reduce fuel consumption by improving engine efficiency and to reduce vehicle mass, friction, and aerodynamics (Advenier et al., 2002; Orasch \& Wirl, 1997). These actions depend largely on the technical costs aimed at improving specific fuel consumption in internal combustion and electrical engines (Koopmanm, 1997). In this sense, transport is the sector with the greatest potential for energy savings through the adoption of technologies to improve energy efficiency (Pimentel et al., 2004).

Operational factors, which refer to the way the vehicle is used, include speed and driving dynamics (Espinosa-Aranda \& García Ródenas, 2012). Operational factors are strongly influenced by the network characteristics of surface transport infrastructure and the number of technical and commercial stops (Burgess \& Choi, 2003; Ng et al., 2006). Transport infrastructure 
determines the nature and design of the accompanying urban fabric and the energy consumption per ton-kilometer carried (Cuddihy et al., 2005). Direct factors only determine one part of the energy consumption of surface freight transport modes.

This article attempts to compare energy consumption and $\mathrm{CO}_{2}$ emissions from freight transport by road with the railway, in a Spanish context, according to certain routes, vehicles, and freight. The energy consumption model estimates presented in this article could be used as dynamic input information to be developed and integrated as a part of an intelligent transportation system (ITS), monitoring the movement of goods to improve energy efficiency and sustainability. In this sense, the article examines the factors that influence energy consumption and associated emissions and it presents energy consumption ratios per equivalent ton-kilometer. It is necessary to stress the difficulty of making such comparisons by taking average fuel consumption levels or emissions as references, so that the comparison is made in precisely applicable terms. This is because fuel consumption results and emissions vary a great deal on the railway. The only change is in the type of freight carried, the type of traction used, and the line profile; the range of train fuel consumption variation per ton carried (with the same load) is from 1 to 17 . If we also vary the size of the train, the empty return ratio, or the emission factor, then variation ranges are much larger (García Álvarez, 2011).

\section{Reviewed Studies on Energy and Emissions}

The ratios of energy consumption and $\mathrm{CO}_{2}$ emissions for freight transport modes in the world are usually expressed in kilowatt-hours per ton-kilometer and grams of $\mathrm{CO}_{2}$ per tonkilometer (Table 1). These ratios are based on various factors such as capacity, speed, and load level (Leonardi \& Baumgartner, 2004). Energy consumption includes the consumption of primary energy and energy used in fuel production and the distribution of electricity ("well to wheel"). Average fuel consumption and emission ratios of freight transport by vans are about three times more than those by trucks (ECMT, 2007; TRENS, 2003; Van Bee et al., 2005). Air transport is approximately 100 times less efficient than the electric railway and 19 times less efficient than the truck (Pérez-Martínez, 2010). According to Table 1, freight transport by pipeline consumes energy levels per ton-kilometer that are similar to electric rail transport ( 1.0 vs. $1.1 \mathrm{kWh} / \mathrm{t}-\mathrm{km})$, and international shipping is the most efficient mode $\left(0.6 \mathrm{kWh} / \mathrm{t}-\mathrm{km}\right.$ and $\left.13.9 \mathrm{gCO}_{2} / \mathrm{t}-\mathrm{km}\right)$.

Lenzen (1999) estimated that the energy consumed by vans was 9 and 23 times greater than that consumed by rigid, articulated trucks in terms of energy consumed per ton-kilometer. Niedzball and Schmitt (2001) compared the energy demand of aircraft with other vehicle systems, and estimated that energy consumption ratios ranged from 0.35 to $0.47 \mathrm{kWh} / \mathrm{t}-\mathrm{km}$ in trucks and from 7.2 to $19.8 \mathrm{kWh} / \mathrm{t}-\mathrm{km}$ in aircraft. This study estimates a fuel consumption ratio of 0.33 to $0.64 \mathrm{kWh} / \mathrm{t}-\mathrm{km}$ in trains, highlighting the discrepancies between different studies and the need to standardize environmental data and method- ologies for estimating fuel consumption and emissions. There are case studies in the literature that investigate the influence of driving conditions on energy consumption (Cillero et al., 2009). Although energy consumption appears less in ships and trains than in vans and trucks, the comparison between modes and submodes is not homogeneous; the energy savings based on average consumption may be lower than expected. For example, a truck operating long distance (internationally) and with a load factor of $100 \%$ consumes less energy than a train with a load factor of $35 \%$ operating domestically.

\section{METHODOLOGY}

\section{Energy Consumption Model}

Energy consumption ratios (Table 1) obtained from "topdown" models are usually based on transport demand and depend on certain national factors such as load factor, operating speed, and transport distance. These ratios measure energy efficiency according to current load factors nationally, 7.3 tons/vehicle for trucks and 283 for trains (Vassallo et al., 2012). Comparing energy consumption between surface freight transport modes based on these ratios could lead to serious errors and biases when circumstances are not comparable, and makes it difficult to draw valid conclusions locally. Alternatively, the use of "bottom-up" mechanical models of energy consumption, like the model used in this article, improves the quality of the estimates. Empirical evidence is needed to ensure better model calibration, and, in this line, we performed tests comparing real consumption data with the model results looking for bias.

First we estimate the energy consumption of freight vehicles by considering losses in transport (i.e., rolling resistance, drag, and energy consumption during acceleration and deceleration), and adjusting the ratios to use equivalent ton-kilometers. The "mechanical model" used in this article (García Álvarez, 2011) to estimate the energy consumption of vehicle type $i$ (freight train of different compositions, articulated trucks, and megatrucks) with engine technology $j$ (mainly diesel and electricity) can be expressed in kilowatt-hours (kWh), as follows:

$$
\begin{aligned}
& C_{i, j}=3.6 \cdot 10^{-4} l_{s} \\
& \times\left\{\begin{array}{l}
{\left[\left(A+A_{c}\right) \cdot M_{r}+B \cdot V^{*}+\left(c_{p} \cdot S_{f}+c_{f} \cdot p_{w} \cdot L\right) \cdot V^{* 2}\right]+} \\
\sum\left[\frac{1}{2}\left(M_{r}+M_{r o t}\right) \cdot V_{\max }^{2}\right] \cdot k_{b} \cdot N_{s}+\sum\left[M_{r} \cdot g \cdot i \cdot k_{s b}\right]
\end{array}\right\} \\
& \times \frac{1}{\eta_{\text {motor }}}+C_{\text {aux }} \frac{1}{\eta_{\text {aux }}}
\end{aligned}
$$

where $l_{s}$ is the total route length $(\mathrm{km}), A$ is the coefficient of rolling resistance through mechanical abrasion (daN/t), $A_{c}$ is the rolling resistance coefficient on curves $(\mathrm{daN} / \mathrm{t}), M_{r}$ is the actual vehicle mass $(\mathrm{t}), B$ is the air intake rate $\left(\mathrm{daN} /(\mathrm{km} / \mathrm{h}), V^{*}\right.$ is the average vehicle speed $(\mathrm{km} / \mathrm{h}), c_{p}$ is the pressure drag coefficient $\left(\mathrm{daN} /(\mathrm{km} / \mathrm{h})^{2} \mathrm{~m}^{2}\right), S_{f}$ is the front section of the vehicle 
Table 1 Average energy consumption and $\mathrm{CO}_{2}$ emissions for different freight transport modes.

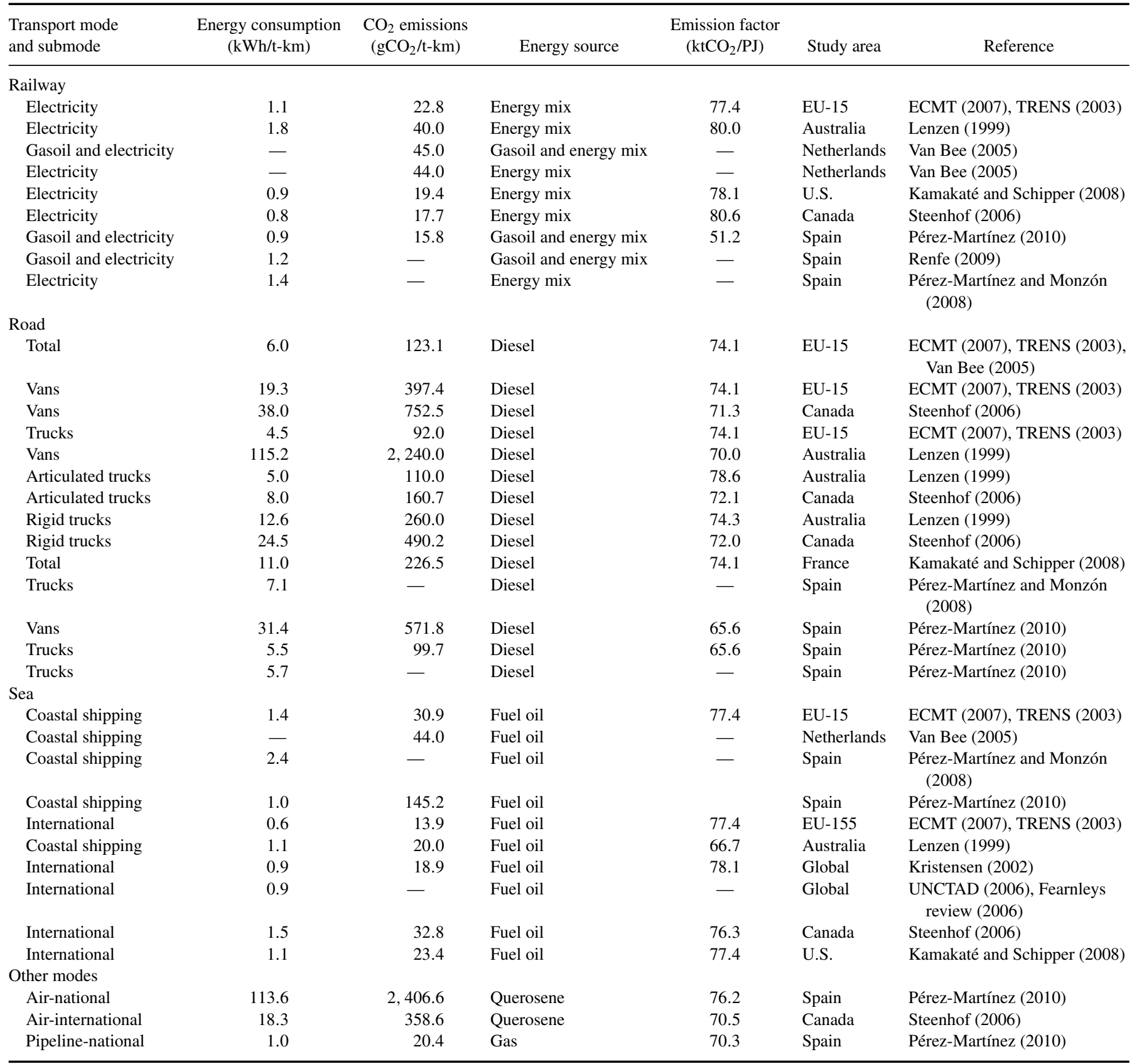

Note. Source: authors' data from different studies (2011).

$\left(\mathrm{m}^{2}\right), c_{f}$ is the friction drag coefficient $\left(\mathrm{daN} /(\mathrm{km} / \mathrm{h})^{2} \mathrm{~m}^{2}\right), p_{w}$ is the wet perimeter $(\mathrm{m}), L$ the length of the vehicle $(\mathrm{m}), M_{\text {rot }}$ is the rotating mass of the vehicle $(\mathrm{t}), V_{\max }^{2}$ is the maximum squared speed $(\mathrm{km} / \mathrm{h})^{2}, k_{b}$ is the braking coefficient (dimensionless), $N_{s}$ is the number of equivalent stops per $100 \mathrm{~km}$ (number of stops $/ 100 \mathrm{~km}), g$ is acceleration of gravity, $9.8\left(\mathrm{~m} / \mathrm{s}^{2}\right), i^{\prime}$ is the slope $(\mathrm{mm} / \mathrm{m})$ for $l_{s}, k_{s b}$ is the braking coefficient on slopes (dimensionless), $\eta_{\text {motor }}$ is the tank-to-wheel efficiency of the vehicle (dimensionless), $C_{a u x}$ is energy consumption of ancillary services $(\mathrm{kWh})$, and $\eta_{\text {aux }}$ is the efficiency of ancillary services (dimensionless). Dividing the preceding expression by $l_{s}$ and by the equivalent tons $t$, equivalent ton-kilometers $\mathrm{t}-\mathrm{km}$, energy consumption is described by the following expression $(\mathrm{kWh} / \mathrm{t}-\mathrm{km})$ :

$$
\begin{aligned}
& C_{i, j}=\frac{3.6 \cdot 10^{-4}}{t} \\
& \times\left\{\begin{array}{l}
{\left[\left(A+A_{c}\right) \cdot M_{r}+B \cdot V^{*}+\left(c_{p} \cdot S_{f}+c_{f} \cdot p_{w} \cdot L\right) \cdot V^{* 2}\right]+} \\
\sum\left[\frac{1}{2}\left(M_{r}+M_{r o t}\right) \cdot V_{\max }^{2}\right] \cdot k_{b} \cdot N_{s}+\sum\left[M_{r} \cdot g \cdot i \cdot k_{s b}\right]
\end{array}\right\} \\
& \times \frac{1}{\eta_{\text {motor }}}+C_{\text {aux }} \frac{1}{\eta_{\text {aux }}} \frac{1}{t \cdot L_{s}}
\end{aligned}
$$


From Eq. 1 we can see how the respective external forces are multiplied by the distance covered $l_{s}(\mathrm{~km})$. In Eq. 1, energy consumption $C_{i, j}$ is determined by seven groups of external forces:

$$
C_{i, j}=F_{r}+F_{r c}+R_{e a}+R_{a e f}+R_{a e p}+E_{k}+E_{p}+C_{a u x}
$$

where $F_{r}$ is the consumption due to rolling resistance, $F_{r c}$ the rolling resistance on curves, $R_{e a}$ is the air intake in the vehicle, $R_{a e f}$ and $R_{a e p}$ are friction and pressure drag, $E_{k}$ is inertial acceleration, $E_{p}$ is gravitational losses, and $C_{a u x}$ is the consumption of ancillary services. Each part of energy consumption contributes to the total energy consumption of vehicle $i$ operating with technology $j$ (diesel and electric), and is represented in the form of energy effort, the product of the external force and the distance traveled. This model, reviewed by Burgess and Choi (2003) and Perez-Martinez and Sorba (2010), has been widely verified, accurately and fairly.

\section{Assumptions, Vehicles, Loads, Lines, and Motorways}

In this article, we do not take into account transport charges, considering that they are common to both the railway and trucks. Distances greater than $300 \mathrm{~km}$ in both directions are considered (OFE, 2009), since in practice the railway does not operate below this distance. Railways and roads used have an average topographic profile ranging between gentle and mountainous. Moreover, we also take into account the fuel consumption of empty runs because their weight is significantly different between the two transport modes.

This also considers the use of each type of product in each transport mode, defining use as an index of net load carried (CNT) and compared with the maximum permissible load (CMA). To isolate the comparative effect of the type of freight carried, car carrier trains and trucks have been chosen as rep- resentative of light freight and petrochemical trains and trucks as representative of dense and heavy goods. With respect to the unit consumption, there is a great difference in both trains and trucks between light and heavy freight, so the analysis has distinguished between types of freight in each of the modes and fuels used. The case of car transport is in particular quite peculiar and different from other types of freight, on both trains and trucks. Limiting the number of cars per wagon or truck is not due to weight, but the volume of the load and the length of the cars, which leads to the relationship between the tare of the wagon or truck and the CNT being very high. For example, an MA5 double-decker car carrier platform wagon, for an average car length of $4 \mathrm{~m}$, can hold 12 vehicles, which is roughly equivalent to 11.75 tons. Therefore, for each net ton 2.36 tons of wagon tare are moved. Conversely, in the transport of petrochemical products 0.37 tons of wagon tare are carried per net ton.

As for the size of the consignment, on the railway net tons vary in the most heavily loaded direction, with it being understood that when the capacity of one wagon is exceeded another one is used. In the case of trucks net tons vary due to the use of mega-trucks and road trains. The engines used in rail transport are 335 series diesel locomotives and 251 series electric locomotives from the Spanish national railway company (RENFE, 2010), and their main characteristics are summarized in Table 2. In the case of the road Euro V, tractive units by the truck maker MAN have been used, with an installed capacity of $353 \mathrm{~kW}$ (MAN, 2011). Table 2 shows, in addition to the technical characteristics of vehicles used in the study (engine type, friction coefficients, air intake, aerodynamics and performance), parameters related to transport operations (speed, vehicle dimensions, loads, masses, and number of axles).

Railway energy consumption is calculated for a simulation of train compositions on two lines, both in up-line and down-line directions, one with a gentle profile (Valladolid-León) and the other with a mountainous profile (León-Gijón) (Figure 1). Thus,

Table 2 Characteristics of the locomotives and trucks used.

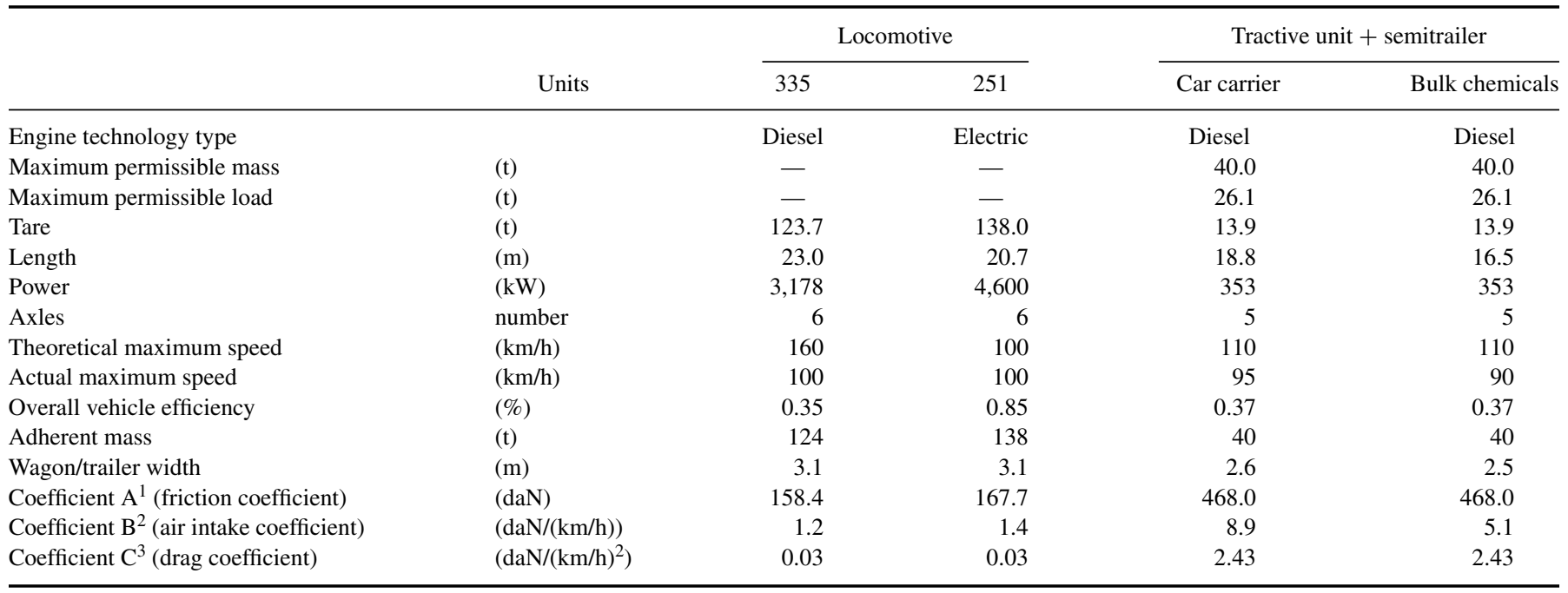

Note. ${ }^{1}$ Sum of coefficients $A$ and $A c$ in Eq. $1 .{ }^{2}$ Comes from Eq. 1. ${ }^{3}$ Expression $\left(c_{p} S_{f}+c_{f} p_{w} L\right)$ in Eq. 1. 

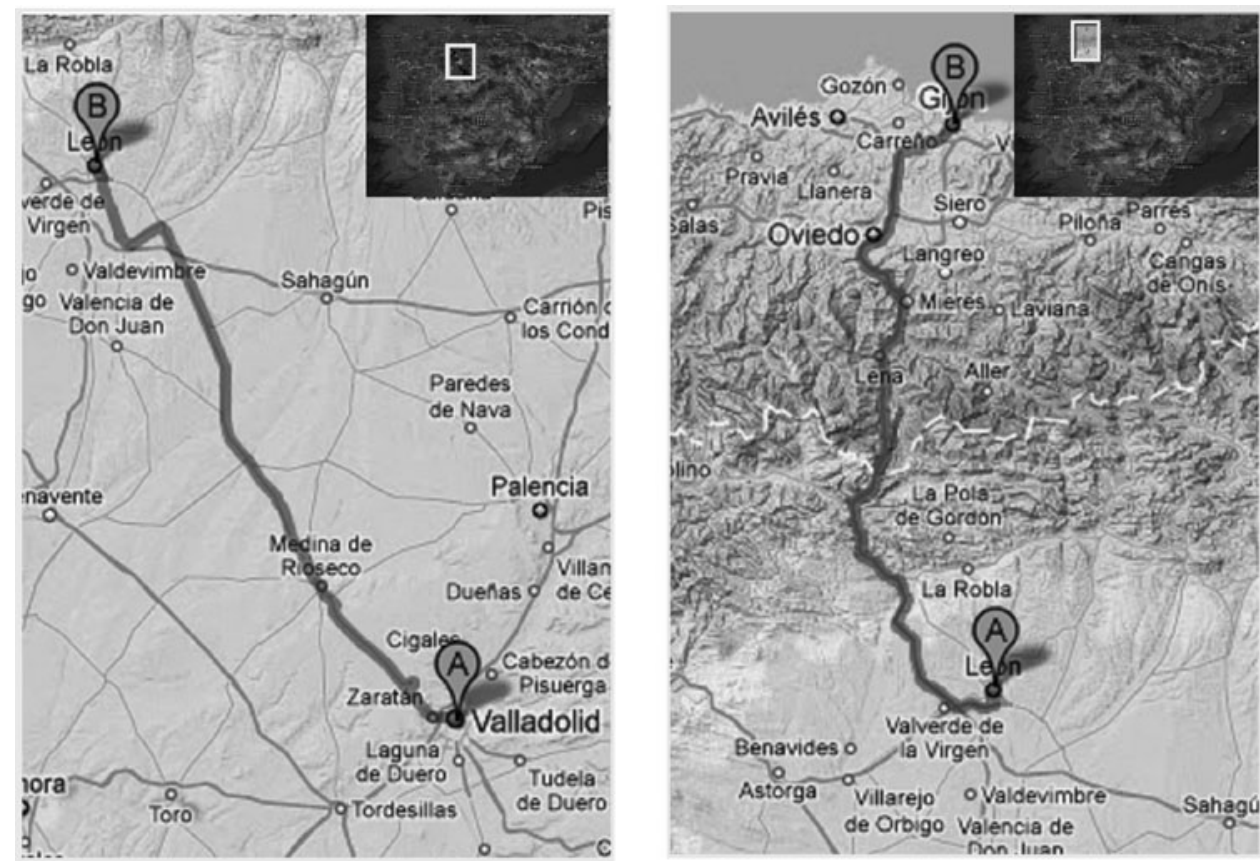

Figure 1 Left: Map of the route corresponding to the flat profile of the Valladolid-León railway line and corresponding motorway. Right: Map of the route corresponding to the mountainous profile of the León-Gijón railway line and motorway. The profiles studied are $171.2 \mathrm{~km}$ long in each direction (railway line) and $158.4 \mathrm{~km}$ long (motorway) for the flat Valladolid-León profile and $171.6 \mathrm{~km}$ and $158.7 \mathrm{~km}$ for the mountainous León-Gijón profile.

the Valladolid-León line has a characteristic upward slope of $12 \mathrm{~mm}$ per meter $(\mathrm{mm} / \mathrm{m})$, is electrified at $3 \mathrm{kV}$ DC, allows a maximum operating speed of $100 \mathrm{~km} / \mathrm{h}$, and has no intermediate stops (Table 3). The average running speed, for both electric and diesel freight trains, is $70 \mathrm{~km} / \mathrm{h}$, similar to that obtained in practice by freight trains in Spain (OFE, 2009). The León-Gijón line, with a characteristic upward slope of $22 \mathrm{~mm} / \mathrm{m}$, is also electrified at $3 \mathrm{kV} \mathrm{DC}$, with the maximum operating speed being $100 \mathrm{~km} / \mathrm{h}$. On this line, we have simulated consumption with no intermediate stops and average speed observed is $70 \mathrm{~km} / \mathrm{h}$. In the case of the roads, we have replaced and replicated the railway lines by motorways with similar profiles, from gentle (Valladolid-León) to mountainous (León-Gijón). Table 3 shows the characteristics of motorway profiles used in the study. Thus, the motorway that connects Valladolid and León has an average upward slope of 0.9 millimeters per meter $(\mathrm{mm} / \mathrm{m})$, allows a maximum operating speed of $105 \mathrm{~km} / \mathrm{h}$, and is considered to have no intermediate stops (in normal conditions without traffic congestion). Similarly, the motorway between León and Oviedo has an average upward slope of 5.3 millimeters per meter $(\mathrm{mm} / \mathrm{m})$ and allows a maximum operating speed of 95 (average speed $85 \mathrm{~km} / \mathrm{h}$ ).

Table 3 Characteristics of line (train) and motorway (truck) profiles.

\begin{tabular}{|c|c|c|c|c|c|c|c|c|c|}
\hline & \multirow[b]{2}{*}{ Units } & \multicolumn{2}{|c|}{$\begin{array}{l}\text { Valladolid-León } \\
\text { section (gentle } \\
\text { line) }\end{array}$} & \multicolumn{2}{|c|}{$\begin{array}{c}\text { Gijón-León } \\
\text { section } \\
\text { (mountainous } \\
\text { line) }\end{array}$} & \multicolumn{2}{|c|}{$\begin{array}{l}\text { Valladolid-León } \\
\text { section (gentle } \\
\text { motorway) }\end{array}$} & \multicolumn{2}{|c|}{$\begin{array}{l}\text { Gijón-León } \\
\text { section } \\
\text { (mountainous } \\
\text { motorway) }\end{array}$} \\
\hline & & Up & Down & Up & Down & SN & NS & SN & NS \\
\hline Length & $(\mathrm{km})$ & 171.2 & 171.2 & 171.6 & 171.6 & 158.4 & 158.4 & 158.7 & 158.7 \\
\hline Tunnel length & $(\mathrm{km})$ & 7.2 & 7.2 & 7.2 & 7.2 & 0 & 0 & 16.9 & 16.9 \\
\hline Height difference & (m) & -143 & 143 & 833 & -833 & -143 & 143 & 833 & -833 \\
\hline Curve coefficient & - & 0.4 & 0.4 & 1.2 & 1.2 & - & - & - & - \\
\hline Height excess & - & 308 & 525 & 1,878 & 5,909 & - & - & - & - \\
\hline Technical stops & number/100 km & 1 & 1 & 1 & 1 & 1 & 1 & 1 & 1 \\
\hline Maximum operating speed & $(\mathrm{km} / \mathrm{h})$ & 100 & 100 & 100 & 100 & 105 & 105 & 95 & 95 \\
\hline Average operating speed & $(\mathrm{km} / \mathrm{h})$ & 70 & 70 & 70 & 70 & 90 & 90 & 85 & 85 \\
\hline
\end{tabular}




\section{Energy Consumption and $\mathrm{CO}_{2}$ Emissions per Ton Kilometer: Homogeneous Units}

To find out the source of the differences in fuel consumption between surface freight transport modes, the energy consumption of the vehicle $i$ (train, conventional truck and mega-truck), with engine technology $j$ (diesel and electric) carrying a cargo of petrochemicals and cars in profile $k$ (gentle and mountainous), $C_{i, j, k}^{\prime}$, is expressed using the following equation:

$$
\begin{aligned}
C_{i, j, k}^{\prime} & =\frac{\text { Fuel consumption (loaded and empty vehicle) }}{\text { Ton kilometres carried }} \\
& =\left(\frac{C_{c}+C_{v} r_{v}}{t_{m} r_{d} r_{a} l_{s}}\right) f_{d}
\end{aligned}
$$

where fuel consumption, with the vehicle loaded $\left(C_{c}\right)$ and empty $\left(C_{v}\right)$, is derived from Eq. 1. This expression is used for both trains with electric traction and trains with diesel traction, and trucks with diesel engines. Because fuel consumption levels per gross ton-kilometer $\left(t_{b}\right)$ vary in each mode, they are converted by a density coefficient $\left(r_{d}\right)$, a load utilization rate $\left(r_{a}\right)$, and an empty run rate $\left(r_{v}\right)$, thereby allowing a homogeneous and representative comparison between modes. Density coefficient $r_{d}$ measures the relationship between the actual net tons that can be carried due to physical constraints $\left(t_{r}\right)$ and the maximum net tons that could theoretically be carried in accordance with current legislation on maximum loads $\left(t_{m}\right)$ :

$$
r_{d}=\left(\frac{t_{r}}{t_{m}}\right) \leq 1
$$

The load utilization rate $r_{a}$ measures the relationship between net tons that are carried $(t)$ and the actual net tons $\left(t_{r}\right)$ :

$$
r_{a}=\left(\frac{t}{t_{r}}\right) \leq 1
$$

The empty run rate $r_{v}$ measures the relationship between vehiclekilometers covered empty $\left(v_{v}\right)$ and vehicle-kilometers covered under load $\left(v_{c}\right)$ :

$$
r_{v}=\left(\frac{v_{v}}{v_{c}}\right)
$$

Finally, the distance factor $\left(f_{d}\right)$ represents the increased journeys to be made by vehicles in different transport modes due to the different routes they cover, the centrality of terminals and access, and dispersal distances in each transport mode. The factor $f_{d}$ is a route coefficient representing a ratio between kilometers traveled $\left(l_{s}\right)$ and existing kilometers in a straight line (orthodromic distance) $\left(l_{o}\right)$ :

$$
f_{d}=\left(\frac{l_{s}}{l_{0}}\right) \geq 1
$$

In this study, we considered equivalent coefficients of 1.428 and 1.321 in the case of freight trains and trucks, respectively (García Álvarez et al., 2009).
Emissions of carbon dioxide $\left(\mathrm{CO}_{2}\right)$ are calculated from the energy in power plant busbars (electric traction) or at oil wells (diesel traction). The following expression is used for the calculation of $\mathrm{CO}_{2}$ emissions:

$$
E_{i, j, k}=C_{i, j, k}^{\prime} \cdot F E_{j}
$$

where $F E_{j}$ is the $\mathrm{CO}_{2}$ emission factor for fuel $j$, mainly electricity and diesel, expressed in grams of equivalent $\mathrm{CO}_{2}$ per kilowatt-hour $\left(\mathrm{gCO}_{2} / \mathrm{kWh}\right)$. The $F E$ for electricity consumed on the Spanish railway, according to the national energy mix, was $246.8 \mathrm{gCO}_{2} / \mathrm{kWh}$ (2009). The $F E$ for diesel fuel consumed on the roads and railways was $262.2 \mathrm{gCO}_{2} / \mathrm{kWh}$ (Pérez-Martínez, 2010). It is obtained by dividing the carbon content of diesel $\left(2,633 \mathrm{~g} \mathrm{CO}_{2} / 1\right)$ by the fuel energy content $(38.3 \mathrm{MJ} / \mathrm{L}$ and 3.6 $\mathrm{MJ} / \mathrm{kWh}$ ), emissions in the "tank to wheel" process, and adding the emissions in the "well to tank" process (14.6 g of fuel per $\mathrm{kWh}$ of final energy). The units finally used in Eq. 4, both for energy in power plant busbars in electricity transport and in tanks in fossil fuel transport, are kWh per net ton-kilometer $(\mathrm{kWh} / \mathrm{t}-\mathrm{km})$; similarly, the units used for carbon dioxide emissions in Eq. 9 are grams of equivalent $\mathrm{CO}_{2}$ per net ton-kilometer $\left(\mathrm{gCO}_{2} / \mathrm{t}-\mathrm{km}\right)$.

\section{ENERGY CONSUMPTION AND CO $\mathrm{O}_{2}$ EMISSION RESULTS}

\section{Parameters}

Table 4 summarizes the average values of the coefficients used in Eq. 4 that were used for each vehicle category and line profile (see nomenclature of Eq. 4). Some coefficients in Table 4 depend on the type of vehicle and fuel used (coefficients of density, utilization, empty runs, and maximum theoretical net tons). In contrast, other coefficients in Table 4 (distance factor and vehicle kilometers traveled) depend largely on the type of route profile (flat or mountainous). According to the results of energy consumption per unit of transport and resulting $\mathrm{CO}_{2}$ emissions, we applied different coefficient values for density $r_{d}$, utilization $r_{a}$, empty runs $r_{v}$, and maximum net tons carried $t_{m}$, depending on the type of vehicle used. In general, trains have higher empty back haul coefficients than trucks (0.8-1.0 vs. 0.23 to 0.46 ), leading to a higher unit consumption of energy. By contrast, the maximum net tons that trains can theoretically carry are higher than in the case of trucks, encouraging savings in fuel consumption and unit emissions. Both trains and trucks have similar density and utilization coefficients since they use similar wagons and trailers.

Distinctive characteristics of different vehicles (Eq. 1 and Table 2), such as the actual mass $M_{r}$, coefficients of rolling resistance due to mechanical friction $A$ and $A_{c}$, the front section of the vehicle $S_{f}$, pressure drag coefficient $c_{p}$, friction drag coefficient $c_{f}$, and drag coefficient $C$, depend on the type of vehicle used and influence fuel consumption and emissions. 
Table 4 Parameters of the homogeneous unit consumption Eq. 4 according to terrain profile, type of fuel used, freight carried, and vehicle.

\begin{tabular}{|c|c|c|c|c|c|c|c|c|}
\hline \multirow[b]{2}{*}{ Vehicle/fuel Freight ${ }^{1}$} & \multicolumn{2}{|c|}{ Train/diesel } & \multicolumn{2}{|c|}{ Train/electric } & \multicolumn{2}{|c|}{ Truck/diesel } & \multicolumn{2}{|c|}{ Mega/diesel } \\
\hline & $\mathrm{pv}$ & gp & $\mathrm{pv}$ & gp & $\mathrm{pv}$ & gp & $\mathrm{pv}$ & gp \\
\hline \multicolumn{9}{|c|}{ Gentle topography (Valladolid-León) } \\
\hline$r_{d}^{2}$ (dimensionless) & 0.90 & 1.00 & 0.90 & 1.00 & 0.90 & 1.00 & 0.90 & 1.00 \\
\hline$r_{a}^{3}$ (dimensionless) & 0.90 & 1.00 & 0.90 & 1.00 & 0.90 & 1.00 & 0.90 & 1.00 \\
\hline$f_{d}^{4}$ (dimensionless) & 1.43 & 1.43 & 1.43 & 1.43 & 1.32 & 1.32 & 1.32 & 1.32 \\
\hline$r_{v}^{5}$ (dimensionless) & 0.80 & 1.00 & 0.80 & 1.00 & 0.23 & 0.43 & 0.26 & 0.46 \\
\hline$C_{c}^{6}(\mathrm{kWh})$ & 8,826 & 6,958 & 3,880 & 3,072 & 992 & 1,442 & 1,264 & 1,838 \\
\hline$C_{v}{ }^{7}(\mathrm{kWh})$ & 7,535 & 4,091 & 3,324 & 1,821 & 910 & 1,261 & 1,159 & 1,607 \\
\hline$t_{m}^{8}(\mathrm{t})$ & 152.7 & 393.0 & 152.7 & 393.0 & 15.0 & 26.1 & 22.6 & 38.7 \\
\hline$l s^{9}(\mathrm{~km})$ & 342.4 & 342.4 & 342.4 & 342.4 & 316.7 & 316.7 & 316.7 & 316.7 \\
\hline $\mathrm{C}^{\prime 10}(\mathrm{kWh} / \mathrm{t}-\mathrm{km})$ & 0.501 & 0.117 & 0.221 & 0.052 & 0.412 & 0.317 & 0.357 & 0.278 \\
\hline$F E^{11}\left(\mathrm{gCO}_{2} / \mathrm{kWh}\right)$ & 262.2 & 262.2 & 246.8 & 246.8 & 262.2 & 262.2 & 262.2 & 262.2 \\
\hline$E^{\prime 12}\left(\mathrm{~g} \mathrm{CO}_{2} / \mathrm{t}-\mathrm{km}\right)$ & 131.3 & 30.7 & 54.4 & 12.8 & 108.1 & 83.2 & 93.7 & 73.0 \\
\hline \multicolumn{9}{|c|}{ Mountainous topography (Gijón-León) } \\
\hline$r_{d}^{2}$ (dimensionless) & 0.90 & 1.00 & 0.90 & 1.00 & 0.90 & 1.00 & 0.90 & 1.00 \\
\hline$r_{a}^{3}$ (dimensionless) & 0.90 & 1.00 & 0.90 & 1.00 & 0.90 & 1.00 & 0.90 & 1.00 \\
\hline$f_{d}^{4}$ (dimensionless) & 1.43 & 1.43 & 1.43 & 1.43 & 1.32 & 1.32 & 1.32 & 1.32 \\
\hline$r_{v}^{5}$ (dimensionless) & 0.80 & 1.00 & 0.80 & 1.00 & 0.23 & 0.43 & 0.26 & 0.46 \\
\hline$C_{c}{ }^{6}(\mathrm{kWh})$ & 15,601 & 15,714 & 6,902 & 6,974 & 1,309 & 1,861 & 1,667 & 2,371 \\
\hline$C_{v}{ }^{7}(\mathrm{kWh})$ & 13,012 & 7,654 & 5,797 & 3,458 & 1,197 & 1,569 & 1,525 & 1,999 \\
\hline$t_{m}^{8}(\mathrm{t})$ & 152.7 & 393.0 & 152.7 & 393.0 & 15.0 & 26.1 & 22.6 & 38.7 \\
\hline$l s^{9}(\mathrm{~km})$ & 343.2 & 343.2 & 343.2 & 343.2 & 317.5 & 317.5 & 317.5 & 317.5 \\
\hline $\mathrm{C}^{\prime 10}(\mathrm{kWh} / \mathrm{t}-\mathrm{km})$ & 0.875 & 0.247 & 0.388 & 0.110 & 0.543 & 0.404 & 0.470 & 0.355 \\
\hline$F E^{11}\left(\mathrm{gCO}_{2} / \mathrm{kWh}\right)$ & 262.2 & 262.2 & 246.8 & 246.8 & 262.2 & 262.2 & 262.2 & 262.2 \\
\hline$E^{\prime 12}\left(\mathrm{~g} \mathrm{CO}_{2} / \mathrm{t}-\mathrm{km}\right)$ & 229.4 & 64.9 & 95.8 & 27.3 & 142.2 & 106.0 & 123.3 & 93.0 \\
\hline
\end{tabular}

Note. ${ }^{1}$ Type of freight: car carriers (pv) and bulk petrochemicals $(\mathrm{gp}) ;{ }^{2}$ density coefficient: actual maximum net tons $\left(t_{r}\right) /$ theoretical maximum net tons $\left(t_{m}\right)$; ${ }^{3}$ utilization rate: net tons carried $(t) /$ actual maximum net tons $\left(t_{r}\right) ;{ }^{4}$ distance factor: actual vehicle-km $\left(l_{s}\right)$ /orthodromic vehicle-km $\left(l_{o}\right)$; ${ }^{5} \mathrm{empty}$ back hauls rate: empty vehicle-km $\left(v_{v}\right) /$ vehicle-km loaded $\left(v_{c}\right) ;{ }^{6}$ loaded vehicle consumption; ${ }^{7}$ empty vehicle consumption; ${ }^{8}$ theoretical maximum net tons; ${ }^{9}$ actual total vehicle-km runs; ${ }^{10}$ energy consumption per unit of transport efficiency; ${ }^{11}$ energy source emission factor, electricity and diesel; ${ }^{12} \mathrm{CO}_{2}$ emissions per transport unit.

Trains have lower coefficients for rolling resistance $A$ and drag $C$ than trucks. For example, $A$ and $C$ increase from $158.4($ daN) and $0.03\left(\mathrm{daN} /(\mathrm{km} / \mathrm{h})^{2}\right)$ in trains to 468.0 and 2.43 in trucks. The actual mass of the vehicle in relation to the maximum net load in tons carried varies considerably between modes and types of freight carried. On average, car carrier trains have four to six times more mass per net ton carried than trucks. For instance, in Spain car carrier trucks can transport 25 net tons (for a tare weight of 12.5 tons) and car carrier trains can transport about 150 net tons ( 6 times more for a tare weight of 1,050 tons). The differences in weight are due to the use of lighter components in road modes and in the demand for safety in railway modes.

The total vehicle kilometers traveled $l_{s}$ and the distance factor $f_{\mathrm{d}}$ depend largely on the type of route profile (flat, mountainous). Fuel consumption in the acceleration and braking processes with the vehicle loaded $C_{c}$ and empty $C_{v}$ depend heavily on the profiles of the lines, as well as on the type of service and consequent driving guidelines (Table 3 ). The frequency and magnitude of these acceleration and braking actions to move a vehicle are different on flat and mountain profiles of roads and railways. For both modes, mountainous profiles involve a greater number of equivalent stops due to speed reduction and lower speeds (average and maximum) than flat profiles (as well as longer travel times). Trains have fewer equivalent stops due to speed reduc- tion on a gentle profile, such as the Valladolid-León, than trucks (1.4 vs. 2.0). In mountainous profiles, such as the León-Gijón, trains have the same number of equivalent stops as trucks (4.0 stops per $100 \mathrm{~km}$ ). In this article, we consider that both trains and trucks are unaffected by congestion, keeping technical stops to a minimum and equal to 1.0 stop per $100 \mathrm{~km}$ (Table 3). Congestion costs in Spain are not as high as they are in other countries of the European Union (EU) since most of the interurban road network is rarely congested (Vassallo et al., 2012). For this reason, the average congestion cost in Spain of $0.959 € \mathrm{ct} / \mathrm{tkm}$ is less than that in Europe, $4.795 € \mathrm{ct} / \mathrm{tkm}$ (Maibach, 2008). The congestion costs can increase substantially on the road access to the main cities during transport charges.

\section{Comparison Between Modes, Profiles, Commodities, and Scale Effect}

The results of total energy consumption for loaded and empty vehicles, according to the type of profile, vehicle, and freight carried, vary between $910 \mathrm{kWh}$ (empty car carrier truck running over flat profile) and $15.714 \mathrm{kWh}$ (train loaded with bulk petrochemicals running over a mountainous profile). These total consumption levels are divided by total net ton-kilometers 

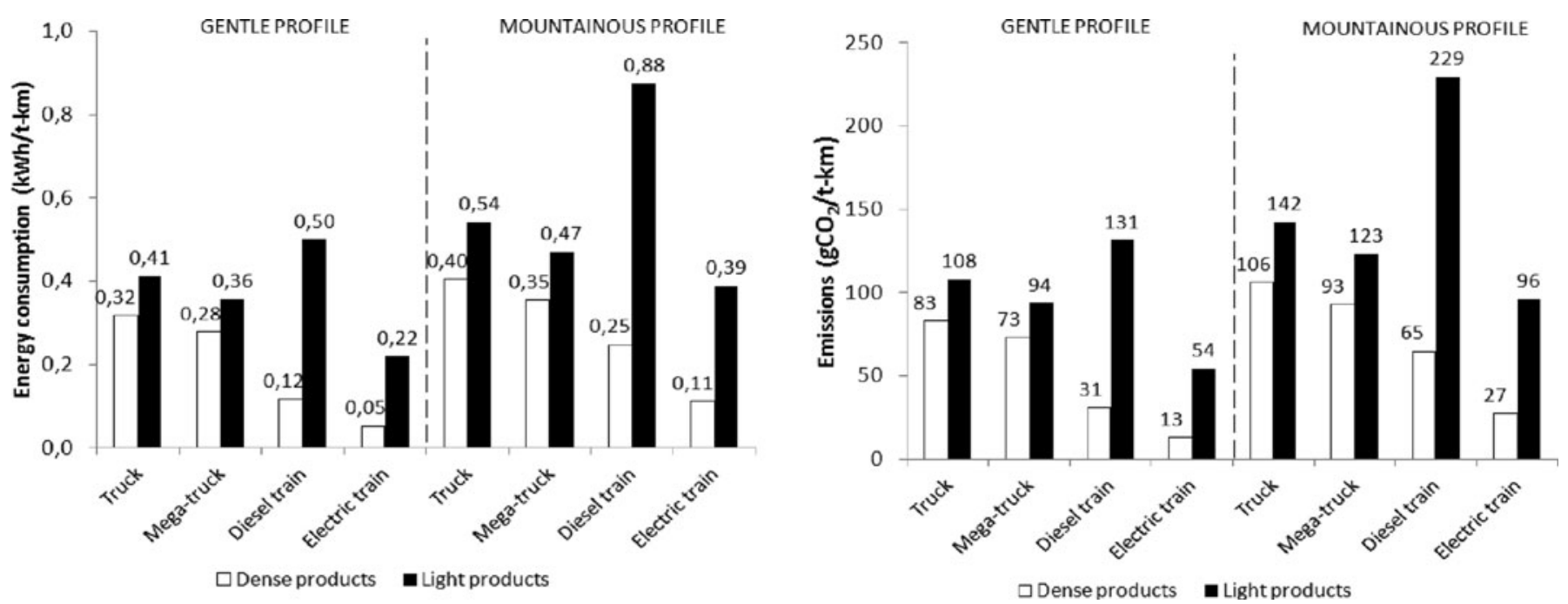

Figure 2 Fuel consumption and emissions of surface freight transport in Spain according to transport mode, profile, and type of freight. The estimated values represent fuel consumption and emissions, on gentle and mountainous profiles for diesel (335) and electric (251) trains, trucks with $40 \mathrm{t}$, and mega-trucks with 60 t of maximum permissible load (CMA), carrying dense products (bulk petrochemicals) and light products (cars).

carried to show a comparison between transport modes, energy source and type of freight (Table 4 and Figure 2). The results of energy consumption per net ton-kilometers carried can be converted into $\mathrm{CO}_{2}$ emissions by using emission factors for the energy source used (mostly diesel and electricity). In general, railway modes consume less energy per unit of transport than road modes except for diesel car carrier trains $(0.05-0.88$ $\mathrm{kWh} / \mathrm{t}-\mathrm{km}$ vs. $0.28-0.54 \mathrm{kWh} / \mathrm{t}-\mathrm{km}$ ).

The results show a greater variation in fuel consumption and emissions in railway modes than in road modes (around 17.6 times on the railway and 1.9 times on the roads). Rail modes show fuel consumption and emission levels depending on the source of energy used, the type of freight carried, and the route profile: Diesel trains carrying bulk petrochemicals over gentle terrain have energy and emission values similar to electric trains carrying bulk petrochemicals over mountainous terrain $\left(0.12 \mathrm{kWh} / \mathrm{t}-\mathrm{km}\right.$ and $31 \mathrm{gCO}_{2} / \mathrm{t}-\mathrm{km}$ vs. $0.11 \mathrm{kWh} / \mathrm{t}-\mathrm{km}$ and 27 $\mathrm{gCO}_{2} / \mathrm{t}-\mathrm{km}$ ), and diesel trains carrying bulk petrochemicals over mountainous terrain have values similar to those for car carrier electric trains on gentle terrain $\left(0.25 \mathrm{kWh} / \mathrm{t}-\mathrm{km}\right.$ and $65 \mathrm{gCO}_{2} / \mathrm{t}-$ $\mathrm{km}$ vs. $0.22 \mathrm{kWh} / \mathrm{t}-\mathrm{km}$ and $\left.54 \mathrm{gCO}_{2} / \mathrm{t}-\mathrm{km}\right)$. Trucks have fuel consumption and emissions values above $0.28 \mathrm{kWh} / \mathrm{t}-\mathrm{km}$ and 73 $\mathrm{gCO}_{2} / \mathrm{t}-\mathrm{km}$ and they are less variable: Mega-trucks carrying bulk petrochemicals over mountainous terrain have energy values similar to car carrier mega-trucks on gentle terrain $(0.35 \mathrm{kWh} /$ $\mathrm{t}-\mathrm{km}$ and $93 \mathrm{gCO}_{2} / \mathrm{t}-\mathrm{km}$ vs. $0.36 \mathrm{kWh} / \mathrm{t}-\mathrm{km}$ and $94 \mathrm{gCO}_{2} / \mathrm{t}-\mathrm{km}$ ), and car carrier trucks on gentle terrain have similar values to those for trucks carrying bulk petrochemicals on mountainous terrain $\left(0.41 \mathrm{kWh} / \mathrm{t}-\mathrm{km}\right.$ and $108 \mathrm{gCO}_{2} / \mathrm{t}-\mathrm{km}$ vs. $0.40 \mathrm{kWh} / \mathrm{t}-$ $\mathrm{km}$ and $\left.106 \mathrm{gCO}_{2} / \mathrm{t}-\mathrm{km}\right)$. The most efficient transport modes over gentle and mountainous profiles are electric trains carrying bulk petrochemicals $\left(0.05 \mathrm{kWh} / \mathrm{t}-\mathrm{km}\right.$ and $13 \mathrm{gCO}_{2} / \mathrm{t}-\mathrm{km}$ vs. 0.11 $\mathrm{kWh} / \mathrm{t}-\mathrm{km}$ and $27 \mathrm{gCO}_{2} / \mathrm{t}-\mathrm{km}$ ), and they consume $8-10$ times less than car carrier diesel trains.
The differences in energy consumption between trains and trucks are similar over flat and mountainous profiles. Differences in energy consumption between transport modes are explained in part by the efficiency of vehicle engines (sum of losses from "well to tank" and "tank to wheel"), higher in electric trains than in diesel trucks and trains. The average efficiency of electric trains and trucks is usually in the range of 34-39\% and $23-24 \%$, respectively. The $15 \%$ difference in efficiency between electric trains and diesel vehicles is explained in part by the use of regenerative braking. Car carrier diesel trains show the highest energy consumption and $\mathrm{CO}_{2}$ emissions on mountainous and gentle profiles. According to the methodology proposed in this article, trains are overall as efficient as trucks (averages of $0.41 \mathrm{kWh} / \mathrm{t}-\mathrm{km}$ and $104 \mathrm{gCO}_{2} / \mathrm{t}-\mathrm{km}$ vs. $0.44 \mathrm{kWh} / \mathrm{t}-\mathrm{km}$ and $\left.116 \mathrm{gCO}_{2} / \mathrm{t}-\mathrm{km}\right)$. However, the variation in estimates for trains is so large (deviations of $\pm 0.33 \mathrm{kWh} / \mathrm{t}-\mathrm{km}$ and $\pm 88 \mathrm{gCO}_{2} / \mathrm{t}-\mathrm{km}$ vs. $\pm 0.08 \mathrm{kWh} / \mathrm{t}-\mathrm{km}$ and $\left.\pm 21 \mathrm{gCO}_{2} / \mathrm{t}-\mathrm{km}\right)$ that they can be as much as 10 times more efficient than trucks in the best case. By contrast, trucks only become three times more efficient than trains in the best case scenario.

Figure 3 shows energy consumption and $\mathrm{CO}_{2}$ emissions in the transport of freight in terms of net tons carried. In general, transport by 335-type diesel locomotives, over both gentle and mountainous profiles and for the transport of both cars and bulk petrochemicals, is the most inefficient mode of transport, even when increasing the number of net tons carried; on the contrary, transport using 251-type electric locomotives in both types of profiles and freight, is the most efficient. According to the results in Figure 3 and for car carrier vehicles, trains consume less energy and emit less $\mathrm{CO}_{2}$ than trucks if they use electrical technology and carry a high volume of net tons (primarily on gentle profiles). In vehicles carrying bulk petrochemicals, trucks are only competitive with diesel trains if they carry a low volume of net tons and over mainly mountainous profiles. The 
Car carrier

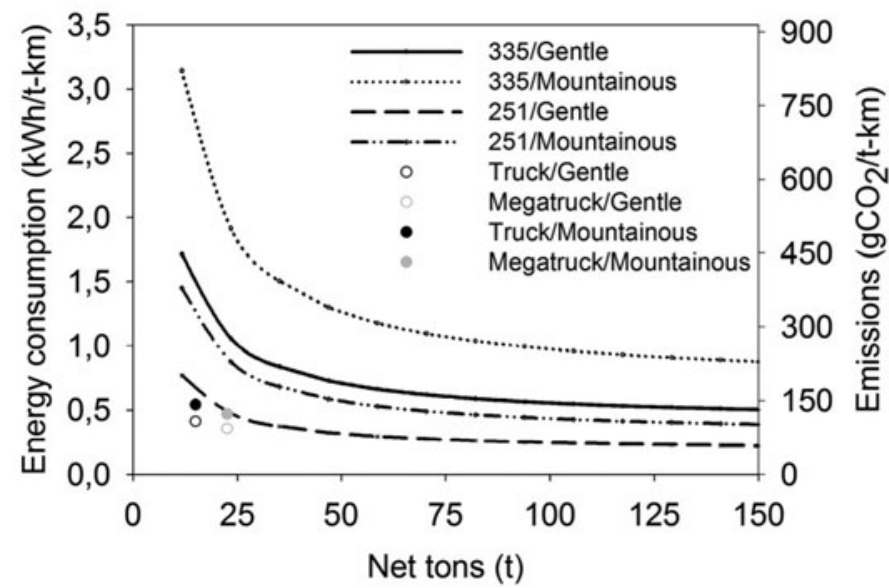

Bulk petrochemicals

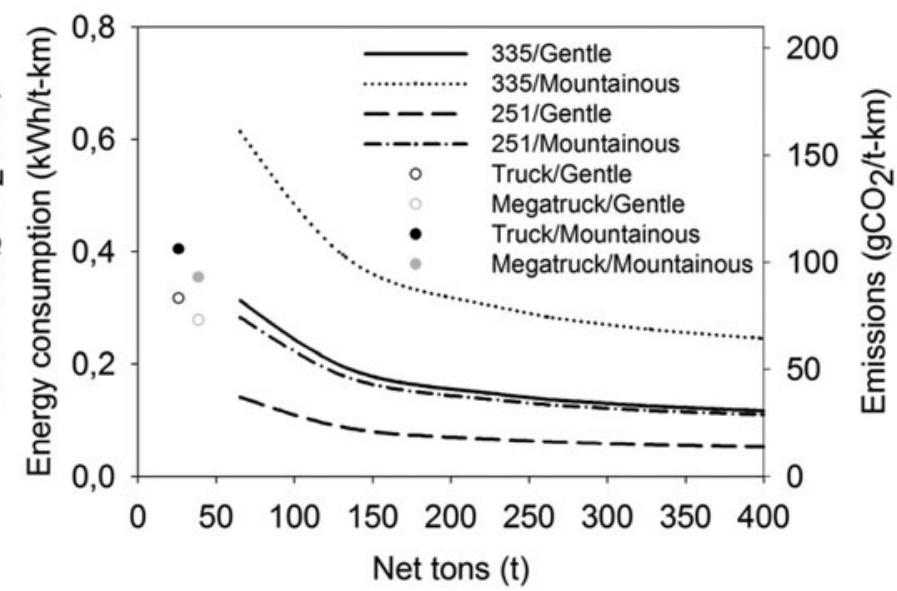

Figure 3 Fuel consumption and emissions of surface freight transport in Spain (rail and road) according to net tons carried. The estimated values represent fuel consumption and emissions for car carrier vehicles (left) and bulk petrochemicals (right), over gentle and mountainous profiles using diesel (335) and electric (251) trains, trucks with $40 \mathrm{t}$, and mega-trucks with $60 \mathrm{t}$ of maximum permissible load (CMA).

results of energy consumption and emissions for the transport of cars and petrochemicals carried by 335 diesel and 251 electric locomotives on lines with gentle and mountainous profiles show asymptotic behaviour. Thus, after 150 net tons carried in cars and 400 tons in bulk petrochemicals there is no increase in energy and emission benefits as a result of the scale effect.

\section{SENSITIVITY ANALYSIS AND ENGINE EFFICIENCY}

Sensitivity analysis of the parameters in Eq. 4 allows us to know the factors that have most influence in unit energy consumption and in $\mathrm{CO}_{2}$ emissions. These parameters determine market niches and sources of improvement in energy consumption. The sensitivity analysis also provides a measurement of the accuracy of the estimates, shown by the contribution to the variance and correlation coefficients (Table 5). Sensitivity analysis can be used to evaluate the contributions of inputs to the variance of unit energy consumption estimates. The results of the analysis show that inputs $t_{m}$ and $C_{c}$, have a significant impact on unit consumption. Unit energy consumption in trains and trucks is more sensitive to maximum net tons carried. Fuel consumption of loaded vehicles is the parameter with the second highest impact on unit consumption and corresponding emissions.

Among vehicles and fuel technologies, the sensitivity analysis shows a different contribution to the variance and correlation coefficients of the most significant parameters (i.e., 0.48 and -0.60 in trains vs. 0.72 and -0.77 in trucks for net tons carried). Unit consumption of trains is less sensitive to net tons carried than unit consumption of trucks. By contrast, unit consumption of trains is more sensitive to consumption, in both loaded and empty vehicles, than unit consumption of trucks.
This study shows that unit energy consumption is mainly influenced by the maximum net tons carried. Increasing the net tons carried by train by $20 \%$ causes the unit consumption to decrease significantly by $19.8 \%$ ( $15.8 \%$ in trucks), mainly by exploiting the load capacity of vehicles. While it is critical to the unit energy consumption and $\mathrm{CO}_{2}$ emissions, the maximum net tons carried is difficult to increase on the road without increasing the maximum permitted size of trucks, unlike the railway, which can easily increase capacity by adding new wagons. Transport logistics should also be considered when trying to increase net tons carried in parallel to increasing the load capacity of vehicles, which is sometimes difficult as evidenced by the evolution in time of vehicle loading factors. However, there are programs and actions to increase these factors, such as the introduction of larger vehicles (60 t mega-trucks) and the development of logistics centres to consolidate loads.

Fuel consumption with the vehicle loaded and empty are the second most important parameters in unit consumption (Table 5). Increasing fuel consumption by $20 \%$, in the train

Table 5 Sensitivity analysis for freight transport consumption with respect to parameter changes (Eq. 4): trains and trucks.

\begin{tabular}{lcc}
\hline Input & Variance contribution & Correlation range \\
\hline Trains: unit energy consumption $(\mathrm{kWh} / \mathrm{t}-\mathrm{km})$ & \\
$\mathrm{t}_{\mathrm{m}}{ }^{1}(\mathrm{t})$ & 0.48 & -0.60 \\
$\mathrm{c}_{\mathrm{c}}{ }^{2}(\mathrm{kWh})$ & 0.38 & 0.53 \\
$\mathrm{c}_{\mathrm{v}}{ }^{3}(\mathrm{kWh})$ & 0.13 & 0.31 \\
Trucks: unit energy consumption $(\mathrm{kWh} / \mathrm{t}-\mathrm{km})$ \\
$\mathrm{t}_{\mathrm{m}}{ }^{1}(\mathrm{t})$ & 0.72 & -0.77 \\
$\mathrm{c}_{\mathrm{c}}{ }^{2}(\mathrm{kWh})$ & 0.22 & 0.43 \\
$\mathrm{c}_{\mathrm{v}}{ }^{3}(\mathrm{kWh})$ & 0.02 & 0.13 \\
\hline
\end{tabular}

Note. ${ }^{1}$ Maximum theoretical net tons; ${ }^{2}$ loaded vehicle consumption; ${ }^{3}$ empty vehicle consumption. Source: authors (2011). 
with the vehicle loaded and empty, causes unit consumption to increase by $18.3 \%$ and $2.4 \%$, respectively $(10.9 \%$ and $3.0 \%$ in the truck). These consumption levels depend largely on the type of route profile, flat and mountainous, as shown by Eqs. 1 and 2. The influence of the type of profile on fuel consumption is mainly due to gravitational losses.

In consumption equation 1 , motor efficiency $\left(\eta_{\text {motor }}\right)$ is the only parameter inversely proportional to the energy of the loaded $\left(C_{c}\right)$ and empty $\left(C_{v}\right)$ vehicle. This is because the improvement in engine efficiency can reduce the energy lost as heat, reducing total energy demand. In this sensitivity analysis, if $\left(\eta_{\text {motor }}\right)$ is improved by $10 \%$, energy consumption could be reduced by $11 \%$. Future enhancements may be directed toward developing new engine technologies and improved fuels (Kaul \& Edinger, 2004; Niedzballa \& Schmitt, 2001). The fuel consumption levels in Table 4 are a combination of total energy and $\mathrm{CO}_{2}$ emissions from "tank to wheel." These values must include energy losses and emissions that occur between primary sources and the vehicle ("well to tank"). In the case of diesel fuel in Spain, these losses are significant (approximately 19\%). The value of $\eta_{\text {motor }}$ in electric trains is higher than diesel engines ( $85 \%$ in this study). However, "well to tank" energy losses are greater and equal to about $60 \%$. The calculation of energy losses and emissions before they reach the vehicle for different types of fuels used in transport and in local circumstances in Spain can be found in López Martínez et al. (2008).

\section{FURTHER ENERGY AND CO $\mathrm{O}_{2}$ EMISSIONS SAVINGS}

Figure 4 shows the distribution of the volume of road freight transport according to the type of freight carried and the resulting associated energy consumption in 2006. The transport of manufactured goods (machinery and vehicles), construction

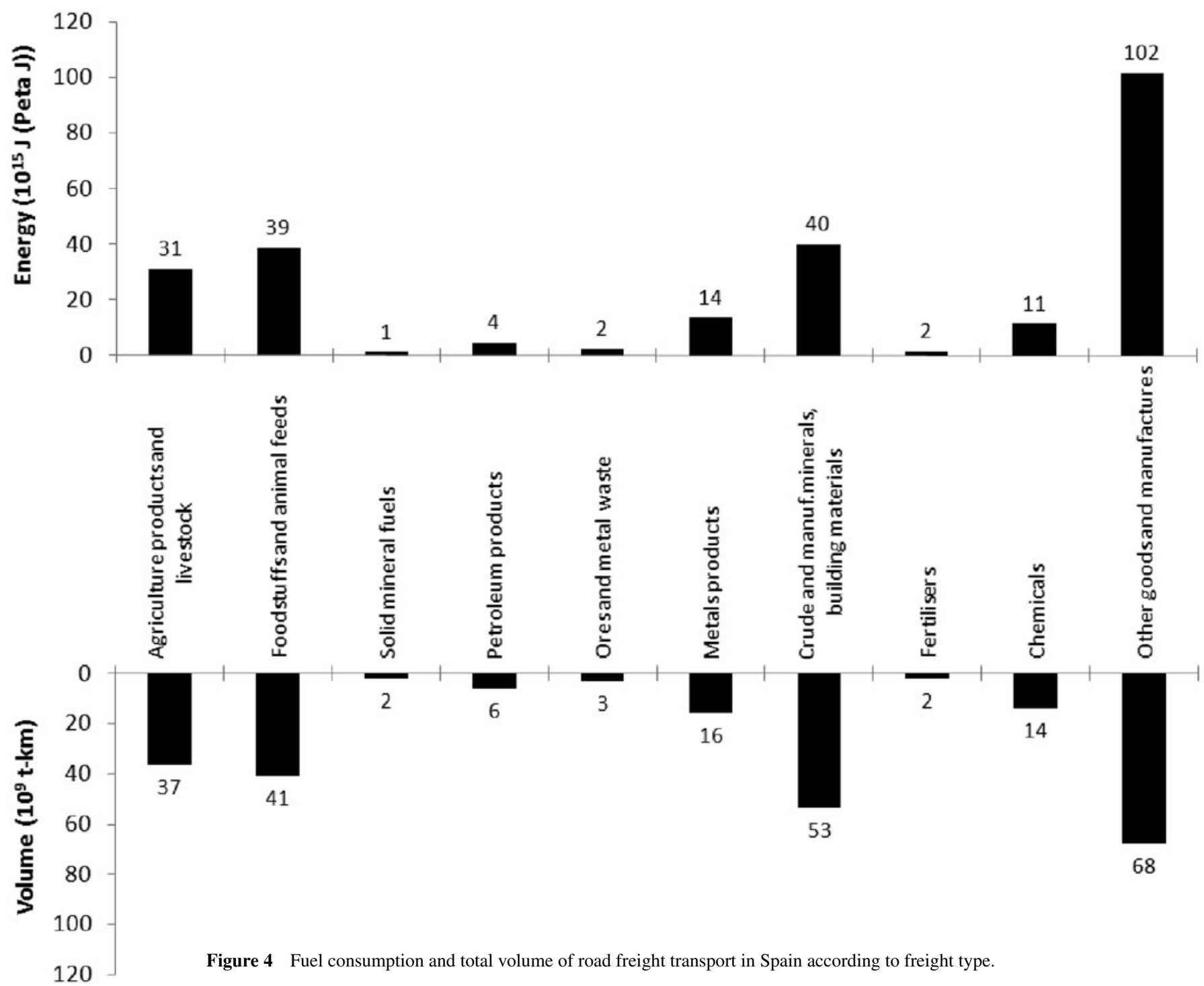


materials (and minerals), food products (and fodder), and agricultural products (and livestock) account for $82 \%$ of the total volume of goods and $86 \%$ of total energy consumption and corresponding $\mathrm{CO}_{2}$ emissions (MFO, 2008). Historically, these types of mostly road products have not been subject to transport by rail in Spain, so the railway carries only about $1 \%$ of these products due primarily to car transport $\left(418 \times 10^{6} \mathrm{t}-\mathrm{km}\right)$. By contrast, the railway has concentrated on the transport of containers $\left(3.981 \times 10^{6} \mathrm{t}-\mathrm{km}\right)$, bulk petrochemicals and coal $(1.925$ $\left.\times 10^{6} \mathrm{t}-\mathrm{km}\right)$, and steel products $\left(2.707 \times 10^{6} \mathrm{t}-\mathrm{km}\right)(\mathrm{OFE}, 2009)$. It is in this market niche that the railway has achieved the highest shares, and it thus carries $29.2 \%$ of all containers, $7.4 \%$ of bulk goods, $5.8 \%$ of cars, and $2.7 \%$ of steel products. The success gained in the transport of containers has led to assessment of a potential transport market for bulk goods and cars up to a market share for surface transport of close to $30 \%$ (more than $20 \%$ increase on current shares). This would achieve higher transport volumes than $7,200 \times 10^{6} \mathrm{t}-\mathrm{km}$ in the case of bulk goods $(276 \%$ increase in volume) and 2,000 $\times 10^{6} \mathrm{t}-\mathrm{km}(387 \%)$ in the case of car carriers respectively.

To estimate the potential energy savings and $\mathrm{CO}_{2}$ emissions in surface freight transport in Spain as a result of a modal shift from trucks to the railway in the case of the two types of freight studied, we considered the savings arising from scenarios studied in this article. In the transport of bulk petrochemicals and car carriers we considered that in the best case scenario for the railway, electric trains on gentle profiles versus trucks on mountainous profiles, trucks consume and emit around 8 and 2.5 times more than the railway (Figure 2). This would mean that 2,520 million $\mathrm{kWh}\left(9.1 \mathrm{TJ}: 10^{15}\right)$ and 0.67 million equivalent tons of $\mathrm{CO}_{2}\left(\mathrm{MtCO}_{2}\right.$ eq.) could have been saved by switching modes in the case of bulk transport: the difference in the unit consumption by trucks over a mountainous profile $(0.40 \mathrm{kWh} / \mathrm{t}-\mathrm{km})$ and the unit consumption of electric trains over gentle profiles $(0.05$, $0.35 \mathrm{kWh} / \mathrm{t}-\mathrm{km}$ ) multiplied by the $\mathrm{t}-\mathrm{km}$ that could potentially be captured by the railroad $\left(7,200 \times 10^{6} \mathrm{t}-\mathrm{km}\right)$. Similarly, 864 million $\mathrm{kWh}(3.1 \mathrm{TJ})$ and $0.23 \mathrm{MtCO}_{2}$ eq. could have been saved when switching modes in the case of car transport: the difference in the unit consumption by trucks over a mountainous profile $(0.54 \mathrm{kWh}$ per ton kilometer) and the unit consumption of electric trains over gentle profiles $(0.22,0.32 \mathrm{kWh}$ per ton kilometer) multiplied by the t-km that the railway aims to capture $\left(2,700 \times 10^{6} \mathrm{t}-\mathrm{km}\right)$. Knowing that the annual consumption of freight transport by road was $245.5 \mathrm{PJ}$ in 2006, the $12.2 \mathrm{PJ}$ ( $0.9 \mathrm{MtCO}_{2}$ eq.) that could be saved would mean $4.9 \%$ of total industry consumption in that year.

\section{CONCLUSIONS AND DISCUSSION}

In estimating the energy consumption of freight transport modes, supposedly representative generic values are often used. But although the average values may (with many limitations) be useful in trucks or aircraft, on the railway this is not the case, due to the substantial variability of this consumption. The variability of consumption on the railway is due to the fact that trains are different from each other in size, type of traction (electric or diesel), and freight carried. In addition, the profiles of the lines also have important differences, due to topography, number of stops, and associated running speeds (this variability ranges from 1 to 17). By contrast, in the case of road freight transport, consumption values are more representative due to the smaller size range of vehicles and the lower incidence causing variation of any of their characteristic parameters. Due to these reasons, it is considered important to indicate what factors cause this variation, what the parameters with highest incidence are, and their order of magnitude, in order to fairly compare and understand the difference between the two.

Unit energy consumption per ton kilometer was estimated for two types of profiles (flat and mountainous) in different vehicles, in both railway and truck systems. These unit consumption levels depend largely on the total consumption of vehicles per kilometer in both loaded and empty vehicles. The results show that the operating parameters that depend on the type of profile, such as speed, number of stops, and braking, have a great influence on the total energy consumption of vehicles and consequent consumption per unit of transport ton kilometer. Parameters depending on the type of vehicle and independent of the type of profile, such as vehicle mass, rolling resistance, and drag, also have a significant impact on energy consumption.

Energy consumption per equivalent ton-kilometer was found to be strongly related to the maximum net tons carried. There is a good correlation between unit energy consumption and maximum net tons carried in trucks, especially in mountainous profiles. The correlation between unit consumption and total consumption, in loaded and empty vehicles, is higher in trains than in trucks. Total consumption relates to the vehicle's mass since almost all the energy losses of the vehicle (rolling resistance, aerodynamics, gravity, and kinetic energy) depend on the vehicle tare. In this sense, trains have better acceleration, lower rolling resistance, and better drag coefficients than trucks, and have lower total consumption per unit mass than trucks. According to the results of this article, a combination of vehicles with a high ratio of net tons carried with respect to tare, with low rolling and drag coefficients, operating in constant speed profiles with few stops, leads to lower energy consumption per equivalent ton kilometer.

The weakest link between unit of energy consumption and $\mathrm{CO}_{2}$ emissions and the type of vehicle is found for electric trains $\left(0.05 \mathrm{kWh} / \mathrm{t}-\mathrm{km}\right.$ and $\left.13 \mathrm{gCO}_{2} / \mathrm{t}-\mathrm{km}\right)$ and petrochemical megatrucks $\left(0.28 \mathrm{kWh} / \mathrm{t}-\mathrm{km}\right.$ and $\left.73 \mathrm{gCO}_{2} / \mathrm{t}-\mathrm{km}\right)$ over flat profiles. By contrast, the strongest link between energy consumption and emissions and the type of vehicle was found for diesel trains $\left(0.88 \mathrm{kWh} / \mathrm{t}-\mathrm{km}\right.$ and $\left.229 \mathrm{gCO}_{2} / \mathrm{t}-\mathrm{km}\right)$ and car carrier trucks $\left(0.54 \mathrm{kWh} / \mathrm{t}-\mathrm{km}\right.$ and $\left.142 \mathrm{gCO}_{2} / \mathrm{t}-\mathrm{km}\right)$ over mountain profiles. The length of the route can also have a significant impact on the unit energy consumption and emissions of different modes of transport, making it necessary to take into account a distance factor $\left(f_{d}\right)$ to estimate energy consumption and to eliminate the effects of poor infrastructure planning. 
The energy consumption estimates could be integrated in ITS to improve planning and operation of the transportation system through the application of new sustainable technologies. In the main results of the study, we cannot assume that "bottom-up" engineering models are always more suitable for analysis and forecasting of consumption. The proposed methodology, broken down by transport modes used at the time, is valid for the current technology of vehicles, and has limitations in the analysis and prediction of new vehicles that could be developed.

\section{REFERENCES}

Advenier, P., Boisson, P., Delarue, C., Douaud, A., Girard, C., \& Legendre, M. (2002). Energy consumption and $\mathrm{CO}_{2}$ emissions of road transportation: Comparative analysis of technologies and fuels. Energy and Environment, 13(4-5), 631-646.

Burgess, S. C., \& Choi, J. M. J. (2003). A parametric study of the energy demands of car transportation: A case study of two competing commuter routes in the UK. Transportation Research Part D, 8(1), 21-36.

Cillero-Hernández, A., Bouzada-Outeda, P., García-Álvarez, A., \& Martín-Cañizares, M. (2009). Métrica y estandarización de los consumos y emisiones en el transporte. Madrid, Spain: Fundación de los Ferrocarriles Españoles.

Cuddihy, J., Kennedy, C., \& Byer, P. (2005). Energy use in Canada: Environmental impacts and opportunities in relationship to infrastructure systems. Canadian Journal of Civil Engineering, 32(1), $1-15$.

European Conference of Ministers of Transport. (2007). Cutting transport $\mathrm{CO}_{2}$ emissions: What progress? Paris, France: European Conference of Ministers of Transport, OECD.

Espinosa-Aranda, J. L., \& García-Ródenas, R. (2012). A discrete eventbased simulation model for real-time traffic management in railways, Journal of Intelligent Transportation Systems, 16(2), 94-107.

FEARNLEYS. (2006). Fearnleys review 2006. Annual report. Oslo, Norway: Fearnresearch.

García-Álvarez, A., Cillero-Hernández, A., Martín-Cañizares, M. P., \& Bouzada-Outeda, P. (2009). Incremento de recorrido en el transporte por longitud de caminos, operación y gestión. Madrid, Spain: Fundación de los Ferrocarriles Españoles.

García Álvarez, A. (2011). Energía y emisiones en el transporte por ferrocarril. Madrid, Spain: Fundación de los Ferrocarriles Españoles.

Kamakaté, F., \& Schipper, L. (2008). Trends in truck freight energy use and carbon emissions in selected OECD countries from 1973 to 2003. Proceedings of the TRB, Report No. 08-1898/19p. Washington, DC.

Kaul, S., \& Edinger, R. (2004). Efficiency versus cost of alternative fuels from renewable resources: Outlining decision parameters. Energy Policy, 32(7), 929-935.

Kristensen, H. O. (2002). Cargo transport by sea and road-technological and economic environmental factors. Marine Technology, 39(4), 239-249.

Koopman, G. J. (1997). Long-term challenges for inland transport in the European Union: 1997-2010. Consequences for transport fuel economy and use. Energy Policy, 25(14-15), 1151-1161.

Lenzen, M. (1999). Total requirements of energy and greenhouse gases for Australian transport. Transportation Research Part D, 4, 265-290.
Leonardi, J., \& Baumgartner, M. (2004). $\mathrm{CO}_{2}$ efficiency in road freight transportation: Status quo, measures and potential. Transportation Research Part D, 9, 451-464.

López Martínez, J. M., Sánchez Alejo, J., Gómez, A., \& Fernández, A. (2008). Flujos del petróleo y del gas natural para el transporte. Monografías EnerTrans/8. Madrid, Spain: Fundación de los Ferrocarriles Españoles.

Maibach, M., Schreyer, C., Suter, D., van Essen, H. P., Boon, B. H., . . Bak, M. (2008). Handbook on the estimation of external costs in the transport sector. Version 1.1. CE Delft, The Netherlands: European Commission DG TREN.

MAN. (2011). (Articulated trucks). Retrieved from http://www. mantruckandbus.es/es/Lkw_TGX/TGX.jsp

MFO. (2008). Encuesta Permanente de Transporte de Mercancías por Carretera 2007 y 1994. Madrid, Spain: Centro de Publicaciones de la Secretaría General Técnica del Ministerio de Fomento.

Ng, S. T., Cheu, R. L., \& Lee, D. H. (2006). Simulation evaluation of the benefits of real-time traffic information to trucks during incidents. Journal of Intelligent Transportation Systems, 10(2), 89-99.

Niedzballa, H. A., \& Schmitt, D. (2001). Comparison of the specific energy demand of aeroplanes and other vehicle systems. Aircraft Design, 4(4), 163-178.

OFE. 2009. Observatorio del Ferrocarril en España. Transporte de mercancías. Madrid, Spain: Fundación Española de los Ferrocarriles.

Orasch, W., \& Wirl, F. (1997). Technological efficiency and the demand for energy (road transport). Energy Policy, 25(14-15), 1129-1136.

Pérez-Martínez, P. J. (2010). Freight transport, energy use and emission trends in Spain. Transport Research Record, 2191, 16-22.

Pérez-Martínez, P. J., \& Monzón, A. (2008). Informe sobre transporte y medio ambiente. Trama 2008. Madrid, Spain: Secretaría General Técnica Ministerio de Medio Ambiente.

Pérez-Martínez, P. J., \& Sorba, I. (2010). Energy consumption of passenger land transport modes. Energy and Environment, 21(6), 577-600.

Pimentel, D., Pleasant, A., Barron, J., Gaudioso, J., Pollock, N., Chae, E., ... Eaton, A. (2004). US energy conservation and efficiency: Benefits and costs. Environment, Development and Sustainability, 6(3), 279-305.

RENFE. (2009). Sustainability report. Madrid, Spain: Alta velocidad RENFE, Gabinete de Calidad y Medio Ambiente.

RENFE. (2010). Parque Material Motor de RENFE operadora. Madrid, Spain: Mercancías, Dirección General de Seguridad, Organización y RR.HH, Dirección Corporativa de Organización, and Desarrollo Gerencia de Comunicación Interna y Cultura Empresarial.

Steenhof, P., Woudsma, C., \& Sparling, E. (2006). Greenhouse gas emissions and the surface transport of freight in Canada. Transportation Research Part D, 11, 369-376.

TRENS. (2003). Calculation of indicators of environmental pressure caused by transport, Main report. Luxembourg: European Commission, Office for Official Publications of the European Communities.

United Nations Conference on Trade and Development. (2006). Review of maritime transport 2005. New York, NY: UNCTAD.

Van Wee, B., Janse, P., \& Van Den Brink, R. (2005). Comparing energy use and environmental performance of land transport modes, Transport Reviews, 25(1), 3-24.

Vassallo, J. M., López, E., \& Pérez-Martínez, P. J. (2012). Do charges to freight trucks and trains in the European Union reflect their social marginal costs? Road \& Transport Research, 21(1), 13-24. 